Pámi V Jónsson, Professor, Faculty of Medicine, School of Health Sciences, University of Iceland and Chief, department of geriatrics, Landspitali University Hospital.

https://doi.org/10.17992/lbl.2017.10.152

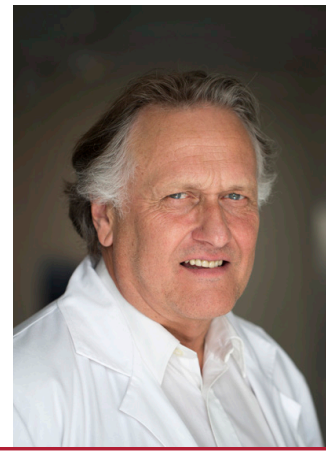

Pálmi V. Jónsson

prófessor við Læknadeild Háskóla Íslands og yfirlæknir öldrunarlækninga á Landspítala

\title{
Öldrunarrannsókn Hjartaverndar
}

Um miðja nítjándu öld voru ævilíkur Íslendinga við fæðingu innan við 50 ár en hafa síðan vaxið jafnt og pétt og eru nú yfir 80 ár. Fyrir hver 4 ár sem við lifum högnumst við um eitt. Einstaklingur sem er 65 ára hefur nú tólf og hálfu ári lengri ævilíkur en við fæðingu. Um tveir priðju hvers fæðingarárgangs nær pessu æviskeiði, stækkandi hlutfall með tíma. Konur hafa premur árum lengri ævilíkur en karlar sem er minnsti munur sem pekkist. Ekki eldast allir á sama hátt og breytileiki einstaklinga vex stórlega með aldri.

Margir af mikilvægustu sigrum heilbrigðispjónustunnar eru fólgnir í pví að hafa breytt bráðum sjúkdómum í langvinna. Eldra fólk safnar ekki aðeins á sig langvinnum sjúkdómum heldur tekur líkaminn víðtækum og miklum aldurstengdum breytingum, sem færa má gild rök fyrir að séu ígildi sjúkdóma. Tökum dæmi. Æðakerfið stífnar með aldri og efri mörk blóðprýstings hækka. Slagbilsháprýstingur er sterkasti áhættupáttur hjarta- og heilaáfalla eldra fólks. Hjartavöðvinn stífnar og leiðir af sér hjartabilun með varðveittu útfallsbroti. Bein taka að rýrna eftir 25 ára aldur hjá báđum kynjum og konur fá hratt beinmassatap á áratugnum eftir tíðahvörf. Afleiðingarnar eru vaxandi brotatíðni með aldri. Petta eru dæmi um aldurstengdar breytingar sem eru svo almennar og algengar að margir telja pær jafnvel eðlilegar en pær reynast ígildi sjúkdómaํ. Sem slíkar eru pær viðfangsefni læknavísindanna. Yfirlitsgreinarnar frá Öldrunarrannsókn Hjartaverndar í pessu hefti Læknablaðsins sýnir vel fram á mikilvægi öldrunarrannsókna.

Rannsóknir sýna að langvinnir sjúkdómar koma fram á sama tíma ævinnar og áður, p.e. í upphafi priðja æviskeiðsins, og tvöfaldast 1 algengi á hverjum 5 árum eftir 65 ára aldur. Af pessu leiðir að ef algengi mjaðmabrota við 65 ára aldur væri 1\% í stað 2\% yrði fjöldi peirra sem hafa hlotið mjaðmabrot við 85 ára aldur 16\% í stað $32 \%$, svo að dæmi sé tekið. Lífsgæði batna og stórlega dregur úr heilbrigðiskostnaði ef unnt er að seinka framkomu langvinnra sjúkdóma.

Fyrsta starf mitt Íslandi að loknu framhaldsnámi í öldrunarlækningum 1989 var að aðlaga sjötta áfanga rannsóknar Hjartaverndar og bæta við öldrunapætti. Forsvarsmenn Hjartavernd- ar keyptu pau rök að rannsóknin væri eins og rauðvín sem vex að gæðum og verðmæti með aldri. Til undirbúnings leitaði ég ráđa hjá forvera mínum í framhaldsnámi við Harvard, Tamörru Harris, sem pá var hjá Bandarísku Öldrunarstofnuninni, og hjá forsvarsmönnum bandarískrar lýðheilsurannsóknar: Established Populations for Epidemiologic Studies of the Elderly, 1981-1993². Fjölmörgum breytum peirrar rannsóknar var bætt við; svo sem vitrænni getu, athöfnum daglegs lífs, gönguhraða, andlegri líðan og já, einnig hjartabilun. Björn Einarsson öldrunarlæknir skoðaði alla pátttakendana sjötta áfanga. Pannig varð sjötti áfanginn eins konar brú að Öldrunarrannsókn Hjartaverndar, par sem Tamörru Harris var kunnug rannsókn Hjartaverndar pegar leitað var að samstarfsaðilum utan Bandaríkjanna. Hjartaverndarrannsóknin var ekki aðeins stór í sniðum heldur tók hún til beggja kynja sem var óvenjulegt fyrir faraldsfræðilegar hjarta- og æðasjúkdóma rannsóknir pess tíma.

Öldrunarrannsókninni hefur verið lýst ítarlega ${ }^{3}$. Hún er fjölfagleg, gefur ýtarlegar svipgerðir og nýtir fremstu rannsóknartækni sem í sumum tilvikum rekur sjúkdóma ellinnar allt aftur til fósturpróunar ${ }^{4}$. Rannsóknin er með öflugustu rannsóknum sinnar tegundar og birtar greinar í hundruðum taldar. Með henni hafa fengist miklir fjármunir og mikilvægt samstarf við erlenda vísindamenn. En öldrunarlæknirinn metur hvað mest hinn mikla fjölda framúrskarandi íslenskra vísindamanna á ýmsum fræðasviðum sem hafa kosið að beina kröftum sínum að öldrunarrannsóknum.

\section{Heimildir}

1 Heilsufar og heilbrigðispjónusta aldraðra á Íslandi, nútíð og framtíð. Pálmi V. Jónsson. Greinargerð í Skýrslu stýrihóps um stefnumótun í málefnum aldraðra til ársins 2015. Heilbrigðis- og tryggingamálaráðuneytið, mars 2003. ISBN: 9979-872-25-X; 100-113. www. heilbrigdisraduneyti.is/media/Skyrslur/stefnum-aldradir.pdf

2 http://www.icpsr.umich.edu/icpsrweb/NACDA/studies/9915

3 Age, Gene/Environment Susceptibility-Reykjavik Study: multidisciplinary applied phenomics. Harris TB, Launer LJ, Eiriksdottir G, Kjartansson O, Jonsson PV, Sigurdsson G, Thorgeirsson G, Aspelund T, Garcia ME, Cotch MF, Hoffman HJ, Gudnason V. Am J Epidemiol. 2007 May 1;165(9):1076-87.

4 Birth size and brain function 75 years later. Muller M, Sigurdsson S, Kjartansson O, Jonsson PV, Garcia M, von Bonsdorff MB, Gunnarsdottir I, Thorsdottir I, Harris TB, van Buchem M, Gudnason V, Launer LJ. Pediatrics. 2014 Oct;134(4):761-70. 